V. M. Buldenko1, V. V. Trush¹, O. L. Kobzar ${ }^{1}$, A. B. Drapailo², S. G. Vyshnevsky², V. I. Kalchenko ${ }^{2}$, A. I. Vovk ${ }^{1}$

1 V. P. Kukhar Institute of Bioorganic Chemistry and Petrochemistry of the National Academy

of Sciences of Ukraine

1, Murmanska Street, 02094, Kyiv-94, Ukraine. E-mail: vovk@bpci.kiev.ua

2 Institute of Organic Chemistry of the National Academy of Sciences of Ukraine

\title{
The assessment of sulfonylcalix[4]arene derivatives as inhibitors of protein tyrosine phosphatases
}

Aim. To compare sulfonylcalix[4]arene derivatives containing ionizable or non-ionizable substituents at the upper rim of the macrocycle as inhibitors of protein tyrosine phosphatase 1B (PTP1B) and other PTPs.

Results and discussion. The properties of sulfonylcalix[4]arene with four phosphonic acid groups introduced at the upper rim were compared with those of the macrocycles containing four non-ionizable tert-butyl or trifluoroacetamide functions. The sulfonylcalix[4]arene tetrakis-methylphosphonic acid was found to inhibit PTP1B with $I C_{50}$ value in the low-micromolar range without selectivity over other PTPs, such as TC-PTP, MEG1, MEG2, SHP2, and PTP $\beta$. At the same time, modification of sulfonylcalix[4]arene with trifluoroacetamide substituents led to inhibition of PTP1B with $I_{50}$ of $1.4 \mu \mathrm{M}$ and 4- to 28 fold selectivity over the other PTPs. In order to understand the ability of inhibiting PTP1B by sulfonylcalix[4]arene with introduced trifluoroacetamide groups the molecular docking and molecular dynamic simulations were performed. The inhibition mechanism was discussed.

Experimental part. The activities of the test compounds in vitro were examined spectrophotometrically measuring the rate of hydrolysis of $p$-nitrophenyl phosphate as a substrate of PTPs. The molecular docking was performed by AutoDock Vina.

Conclusions. This study can start an approach to develop new inhibitors of PTPs by variations in the nonionogenic substituents on the upper rim of sulfonylcalix[4]arene scaffold.

Key words: sulfonylcalix[4]arene; protein tyrosine phosphatase; inhibition; molecular docking; molecular dynamics

В. М. Булденко, В. В. Труш, О. Л. Кобзар, А. Б. Драпайло, С. Г. Вишневський,

В. І. Кальченко, А. І. Вовк

Оцінка похідних сульфонілкалікс[4]арену як інгібіторів протеїнотирозинфосфатаз

Мета роботи. Порівняння похідних сульфонілкалікс[4]арену, які містять здатні та нездатні до іонізації залишки на верхньому вінці макроциклу, як інгібіторів РТР1В та інших протеїнотирозинфосфратаз.

Результати та їх обговорення. Властивості сульфонілкалікс[4]арену з чотирма фоссонатними групами, приєднаними до верхнього вінця макроциклу, порівнювалися з властивостями сполук, які містять чотири трет-бутильні або трифторацетамідні замісники. Було встановлено, що сульфонілкалікс[4]арентетракіс-метилфосфонова кислота інгібує РТP1В зі значенням IC ${ }_{50}$ в низькомікромолярному діапазоні без селективності стосовно інших РTРаз, таких як TC-PTP, MEG1, MEG2, SHP2 та PTPß. Модифікація сульфонілкалікс[4]арену залишками трифрторацетаміду забезпечила інгібування PTP1B зі значенням IC $\mathrm{ID}_{50} 1,4$ мкM з 4-28-кратною селективністю відносно інших РТРаз. Для з'ясування інгібувальної здатності похідної сульфонілкалікс[4]арену з трифрторацетамідними замісниками відносно РТР1В було застосовано молекулярний докінг та моделювання методом молекулярної динаміки. Обговорюється можливий механізм інгібування.

Експериментальна частина. Активність сполук досліджували спектрофотометрично, вимірюючи швидкість ферментативного гідролізу п-нітрофренілфосфрату як субстрату протеїнотирозинфоссфатаз. Молекулярний докінг було виконано за допомогою AutoDock Vina.

Висновки. Це дослідження може бути основою нового підходу до розробки інгібіторів РТРаз шляхом модифікації верхнього вінця сульфонілкалікс[4]аренового каркасу неіоногенними замісниками.

Ключові слова: сульфонілкалікс[4]арен; протеїнотирозинфоссратаза; інгібування; молекулярний докінг; молекулярна динаміка

В. Н. Булденко, В. В. Труш, О. Л. Кобзарь, А. Б. Драпайло, С. Г. Вишневский,

В. И. Кальченко, А. И. Вовк

Оценка производных сульфонилкаликс[4]арена как ингибиторов протеинтирозинфоосфатаз

Цель работы. Сравнение производных сульфонилкаликс[4]арена, содержащих способные и не способные к ионизации остатки на верхнем ободе макроцикла, как ингибиторов РТР1В и других протеинтирозинфосфатаз.

Результаты и их обсуждение. Свойства сульфонилкаликс[4]арена с четырьмя фосфонатными группами, закрепленными на верхнем ободе макроцикла, сравнивались со свойствами соединений, содержащих mpem-бутильный или трифторацетамидный остатки. Было установлено, что сульфонилкаликс[4] арен-тетракис-метилфосфроновая кислота ингибирует РTP1В со значением $\mathrm{IC}_{50}$ В низкомикромолярном диапазоне без селективности по отношению к другим PTPазам, таким как TC-PTP, MEG1, MEG2, SHP2 и РТРß. Модификация сульфонилкаликс[4]арена остатками трифторацетамида привела к ингибированию PTP1B со значением IC 50 1,4 мкм и 4-28-кратной селективности по отношению к другим РТРазам. Для выяснения ингибирующей способности сульфонилкаликс[4]арена с трифторацетамидными заместителями относительно РТР1В были выполнены молекулярный докинг и моделирование методом молекулярной динамики. Обсуждается возможный механизм ингибирования.

Экспериментальная часть. Активность соединений исследовали спектрофотометрически, измеряя скорость ферментативного гидролиза п-нитрофенилфосфрата, используемого в качестве субстрата протеинтирозинфоссратаз. Молекулярный докинг был выполнен с помощью AutoDock Vina.

Выводы. Это исследование может быть основой нового подхода к разработке ингибиторов РТРаз путем модификации верхнего обода сульфонилкаликс[4]аренового каркаса неионогенными заместителями.

Ключевые слова: сульфонилкаликс[4]арен; протеинтирозинфосфратаза; ингибирование; молекулярный докинг; молекулярная динамика 
The addition or removal of a phosphoryl group in proteins is known to control their stability, and modulate the enzyme activity. Approximately $30 \%$ of cellular proteins can be in a phosphorylated form [1]. Tyrosine phosphorylation is essential for many cellular processes, such as growth, differentiation, survival, cell communications, cell migration, and the immune response [2]. Aberrant tyrosine phosphorylation proved to be associated with human diseases, including cancers, diabetes, rheumatoid arthritis, and hypertension $[3,4]$. During the last decade, the extensive data concern the activity of PTP1B leading to inhibition of insulin signaling, and the activity of SHP-2 as an oncogene and promoter of the growth factor signaling $[2,5]$. In those instances where the PTPs activity is inappropriately high the inhibitors of these enzymes can be regarded as possible therapeutic agents. Although such agents are permanently studied, PTPtargeted drugs have not yet been available. It is all because the highly charged and highly conserved nature of the PTP active site. For this reason, potent inhibitors of PTPs tend to have a negatively charged group, which may limit their cell permeability and bioavailability.

Such synthetic macrocycles as calixarenes have diverse applications in chemistry and biology [6-8] due to their unique conformational features and the possibility for modifications both at lower and upper rims $[9,10]$. It has been shown that calix [4]arenes can be useful as a platform for designing bioactive compounds with the possibility of targeting enzymes and other proteins [11]. For instance, calix[4] arene derivatives with covalently bound phosphonic acid groups exhibit inhibitory effects towards PTP1B and some other PTPs [12]. We also observed that phosphonate monoesters on the thiacalix[4]arene framework were more effective and selective PTP1B inhibitor [13]. An unsubstituted sulfonylcalixarene containing four bridging $\mathrm{SO}_{2}$-groups turned out to be promising bioactive compound with the inhibitory activity towards protein tyrosine phosphatase MEG2 and selectivity over some other PTPs [14]. These data provided a basis for further investigation of sulphonylcalix[4]arene derivatives in searching for substances with desired biological properties. Our next efforts for designing the macrocyclic inhibitors of PTPs directed towards sulfonylcalixarenes contained: i) noncleavable phosphonic acid groups, which mimicked the phosphorylated tyrosine fragment and ii) nonionizable functions, such as tert-butyl or trifluoroacetamide groups, which could improve the cell permeability. The aim of this work was to compare the structural diverse sulfonylcalix[4]arene derivatives containing ionizable or non-ionizable substituents at the upper rim of the macrocycle as inhibitors of PTP1B and other PTPs.
Inhibitory activities of sulfonylcalix[4]arene derivatives 1-3 (Fig. 1) were assessed in vitro against PTP1B, T-cell protein tyrosine phosphatase (TC-PTP), Src homology-2 domain containing protein tyrosine phosphatase 2 (SHP2), megakaryocyte protein-tyrosine phosphatases MEG1 and MEG2, and PTP $\beta$. In the experiments, $p$-nitrophenyl phosphate was used as a substrate. The values of $\mathrm{IC}_{50}$ were calculated from dose-dependent curves as concentrations of the test compound, which decreased the enzyme activity to $50 \%$.

As seen from Tab. 1, sulfonylcalix[4] arene tetrakismethylphosphonic acid $\mathbf{1}$ demonstrated approximately the same inhibition effects on the activities of all PTPs in the low micromolar range of $\mathrm{IC}_{50}$ values, and there was no selectivity for one over the other. Replacement of the phosphonic acid groups with tertbutyl substituents resulted in a dramatic decrease in the inhibitory effect of the less charged compound. The sulfonylcalix[4] arene 2 functionalized by the nonionizable tert-butyl group was a weak inhibitor of PTP1B, MEG2, SHP2, and PTP $\beta$ and did not affect the activity of TC-PTP, MEG1. At the same time, the modification of sulfonylcalix[4]arene with trifluoroacetamide substituents (compound 3) provided the inhibition of PTP1B with $\mathrm{IC}_{50}$ value of $1.4 \mu \mathrm{M}$ and 4 - to 28 fold selectivity over the other PTPs. In this case, the selective inhibition of PTP1B can be attributed to the non-phosphonate upper rim substituents of sulfonylcalix[4] arene 3.

According to the Lineweaver-Burk plots, the effect of inhibitors 3 on the activity of PTP1B was in agreement with a competitive type of inhibition (Fig. 2). The apparent $K_{\mathrm{i}}$ value was of $1.5 \mu \mathrm{M}$. The inhibition mechanism suggests that sulfonylcalix[4]arene derivative 3 bound by the enzyme at the substrate binding site.

The molecular modeling by AutoDock Vina was performed to get insights into the binding mechanism of compound 3 with PTP1B. Two groups of X-ray structures of PTP1B having the open or closed WPD-loop were used for the calculations. It is known that the calix[4]arene backbone exists in four different conformations, they are cone, partial cone, 1,2-alternate,

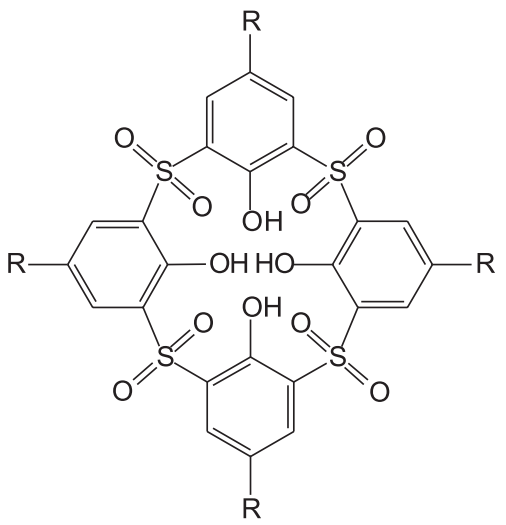

$\mathrm{R}=\mathrm{CH}_{2} \mathrm{PO}(\mathrm{OH})_{2}(1) ; \mathrm{R}=$ tert-But (2); $\mathrm{R}=\mathrm{NHC}(\mathrm{O}) \mathrm{CF}_{3}(3)$

Fig. 1. Chemical structures of sulfonylcalix[4]arene derivatives 1-3 
Table 1

Sulfonylcalix[4]arene derivatives 1-3 as inhibitors of protein tyrosine phosphatases*

\begin{tabular}{|c|c|c|c|c|c|c|}
\hline Inhibitor & PTP-1B & TC-PTP & MEG2 & MEG1 & SHP2 & PTP- $\beta$ \\
\hline 1 & $0.17 \pm 0.04$ & $0.4 \pm 0.01$ & $0.23 \pm 0.04$ & $0.2 \pm 0.04$ & $0.35 \pm 0.01$ & $0.3 \pm 0.04$ \\
\hline 2 & $8.13 \pm 1.1$ & $\mathrm{n} / \mathrm{i}^{* *}$ & $18 \pm 4.1$ & $\mathrm{n} / \mathrm{i}$ & $14 \pm 5.9$ & $11 \pm 1.4$ \\
\hline 3 & $1.4 \pm 0.26$ & $9.6 \pm 0.26$ & $5.73 \pm 0.5$ & $40 \pm 2$ & $11 \pm 4$ & $38 \pm 4$ \\
\hline
\end{tabular}

Notes: $*-\mathrm{IC}_{50}$ values are the means of 2-3 assays \pm standard deviations; $* *-$ No inhibition was observed at $10 \mu \mathrm{M}$

and 1,3-alternate, depending on the number and nature of substituents at the lower or upper rim [15]. The molecular docking of these four conformers of compound 3 to the active site of PTP1B (PDB codes were 1NL9, 1PH0, 1Q6M, 2CM8) showed that there were no sufficient differences in the docking energy calculated for the conformations with the open and closed WPD-loop (Tab. 2).

The docking results obtained for sulfonylcalix[4] arene-tetrakis-trifluoroacetamide $\mathbf{3}$ were further optimized by 1 ns molecular dynamics simulations to assess the complex stability. After the molecular docking operations, the most favorable PTP1B structure was chosen to be with the open WPD loop (PDB code 1NL9). The 1 ns MD simulation was carried out for PTP1B alone, as well as in complexes with compound $\mathbf{3}$ represented by four conformations. The root mean square deviation (RMSD) was calculated for backbone atoms of the crystal structure in order to monitor its structural changes. As shown in Fig. 3, the final RMSD values for all simulation trajectories were less than $1.5 \AA$, indicating that the enzyme structures had reached the equilibrium states with little alterations during the entire simulations. It should be noted that the cone conformation of compound $\mathbf{3}$ had a little higher alterations during the complexation with PTP1B sug-

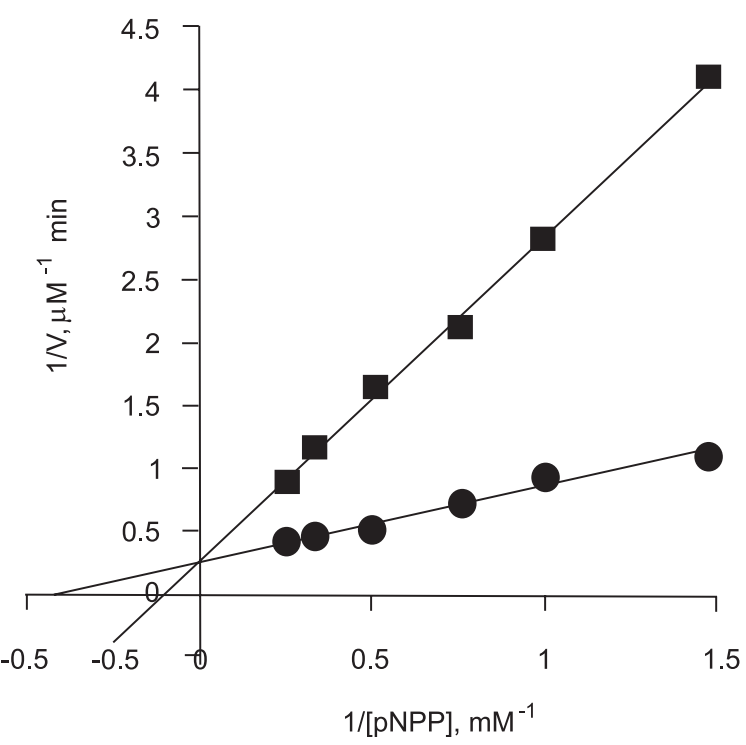

Fig. 2. The Lineweaver-Burk plot for inhibition of PTP1B by trifluoroacetamide derivative of sulfonylcalix[4]arene. The concentration of inhibitor 3 was $1.5 \mu \mathrm{M}$ gesting its lower preferability in comparison with three others. The analysis of the ligand positioning after $1 \mathrm{~ns}$ molecular dynamics simulation was followed by rescoring with Autodock Vina to find out the final free energies of binding, which were -8.25, -7.7, -9.34, and $-6.91 \mathrm{kcal} / \mathrm{mol}$ for cone, partial cone, 1,2-alternate, 1,3-alternate conformers, respectively. This results suggested that the 1,2-alternate conformation was the most preferable.

The root mean square fluctuations (RMSF) being a significant parameter to study the motion of the key residues interacted with the ligand were calculated for all amino acid residues of the PTP1B. The key amino acids residues that are important for the substrate and inhibitors binding to PTP1B belong to P-loop (His214-Arg221), WPD loop (Thr177-Pro185), the substrate recognition loop (Lys36, Val49, and Lys120), and the secondary binding site (Tyr20-Phe52, and Arg254) [16-18]. As compared to free protein, most of the residues of the enzyme-inhibitor complex had lower RMSF values less than $1.4 \AA$ (Fig. 4). These data point that binding of compound 3 reduced the flexibility of the active site residues, thus leading to the stable complex.

The analysis of the complex of compound $\mathbf{3}$ with PTP1B (Fig. 5) showed that one of phenyl rings of the inhibitor was involved in the $\pi-\pi$ interaction with Phe182 of the WPD-loop. There were hydrogen bonds between $\mathrm{SO}_{2}$ groups of the sulfonylcalixarene skeleton and amino acid residues Lys116, Gly183, Arg221, Gln266, and Gln262. One OH group on the bottom rim of the macrocyclic scaffold formed hydrogen bonds with Gln266 and Thr263. An additional set of hydrogen bonds was provided by trifluoroacetamide functions and residues of Arg24 and Arg221. Two of the

Table 2

Free energy of binding of compound 3 into the active site of PTP1B

\begin{tabular}{|c|c|c|c|c|}
\hline \multirow{2}{*}{$\begin{array}{c}\text { Conformation } \\
\text { of the ligand }\end{array}$} & \multicolumn{4}{|c|}{$\Delta \mathrm{G}(\mathrm{kcal} / \mathrm{mol})$} \\
\cline { 2 - 5 } & $1 \mathrm{NL9}$ & $1 \mathrm{PH} 0$ & $1 \mathrm{Q} 6 \mathrm{M}$ & $2 \mathrm{CM} 8$ \\
\hline Cone & -8.6 & -8.5 & -8.1 & -6.3 \\
\hline Partial cone & -7.2 & -7.5 & -7.7 & -7.4 \\
\hline 1,2-Alternate & -7.4 & -7.4 & -7.4 & -5.7 \\
\hline 1,3-Alternate & -7.2 & -6.7 & -6.9 & -6.1 \\
\hline
\end{tabular}




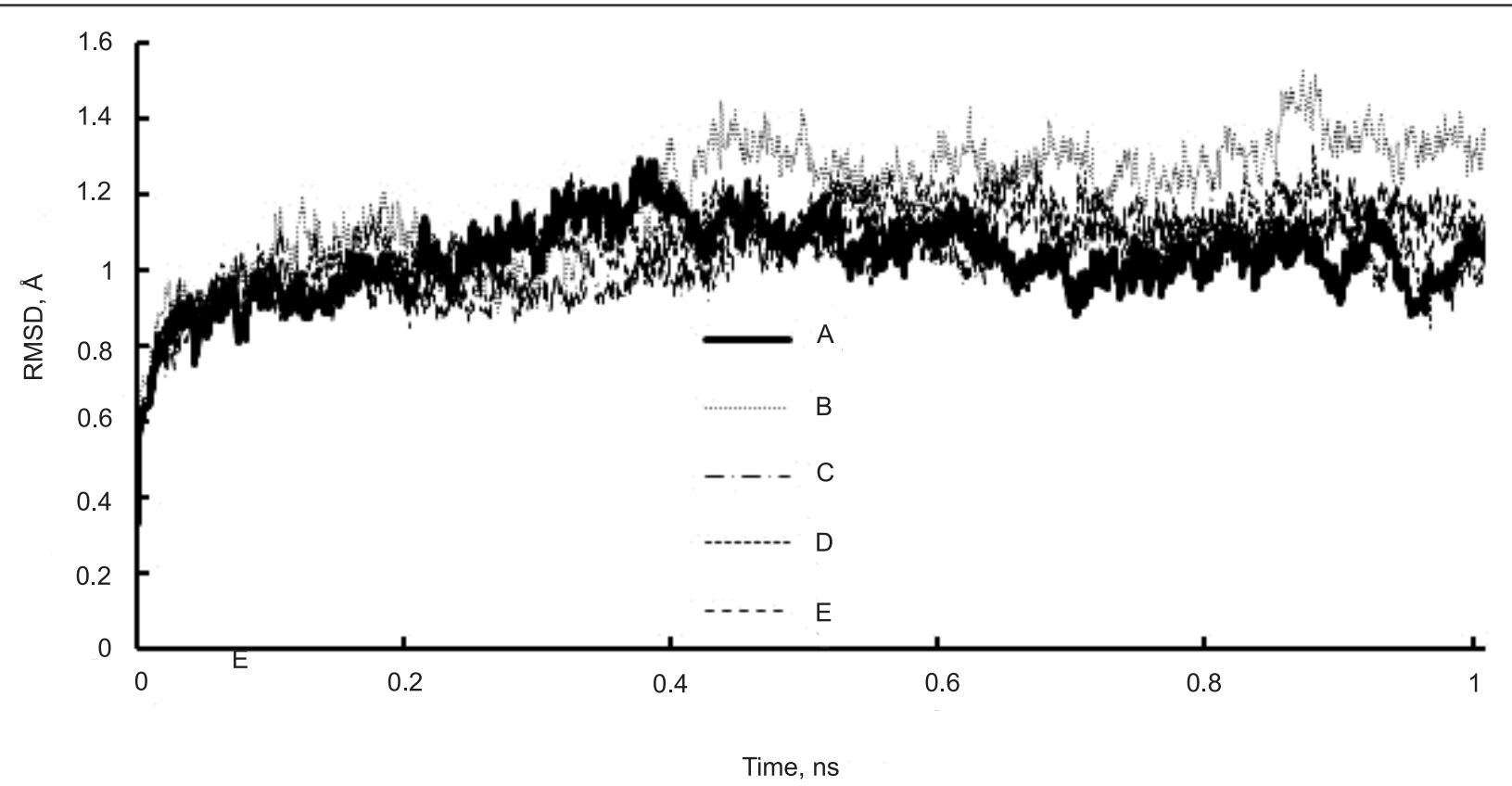

Fig. 3. The RMSD results of molecular dynamic simulations for PTP1B in complex with compound 3. (A) Free enzyme;

(B) PTP1B in complex with the inhibitor in the cone conformation; (C) PTP1B in complex with the inhibitor in the partial cone conformation;

(D) PTP1B in complex with the inhibitor in the 1,2-alternate conformation; (E) PTP1B in complex with the inhibitor in the 1,3-alternate conformation

upper-rim substituents were directed to the region of the active site of PTP1B preventing the access of the substrate to Cys215.

\section{Experimental section}

Commercially available protein tyrosine phosphatases PTP1B, TC-PTP, MEG1, MEG2, SHP2, and PTP $\beta$ were purchased from Sigma-Aldrich. Previously de- veloped protocols were used for the synthesis of sulfonylcalix[4]arene tetrakis-methylphosphonic acid $\mathbf{1}$ [19], tetrakis-tert-butylsulfonylcalix[4]arene 2 [20, 21], sulfonylcalix[4] arene-tetrakis-trifluoroacetamide 3 [22].

\section{The in vitro study of PTPs inhibition}

The assay solution contained $50 \mathrm{mM}$ Bis-Tris (pH 7.2), $1 \mathrm{vol} \%$ of dimethyl sulfoxide, $100 \mathrm{mM} \mathrm{NaCl}, 2 \mathrm{mM}$ DTT, 3 mM EDTA. Concentrations of $p$-nitrophenyl phos-

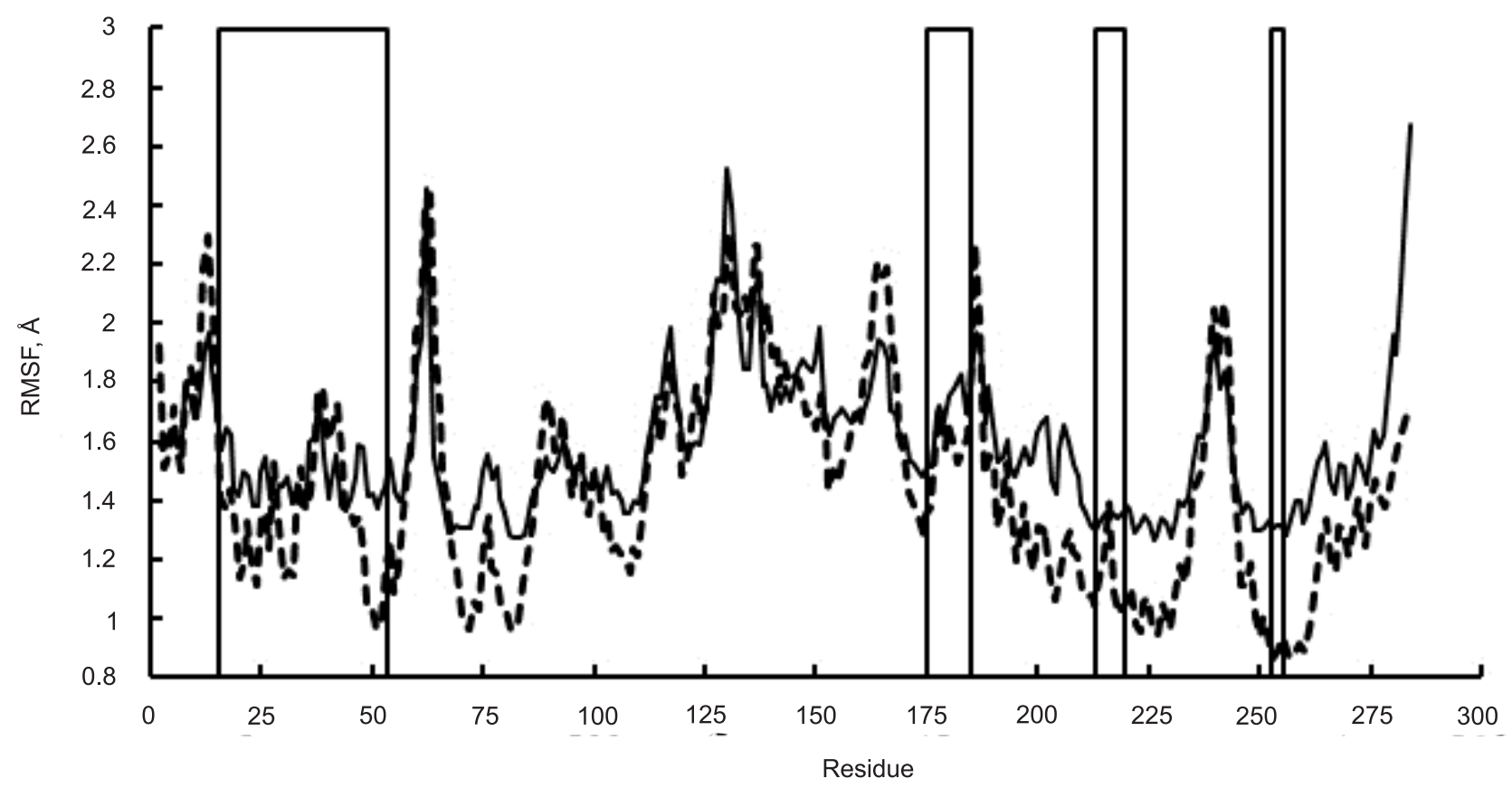

The RMSF results for PTP1B

--- PTP1B in complex with the 1,2-alternate conformer of compound 3

Fig. 4. The RMSF results for PTP1B and PTP1B in complex with the 1,2-alternate conformer of compound 3 


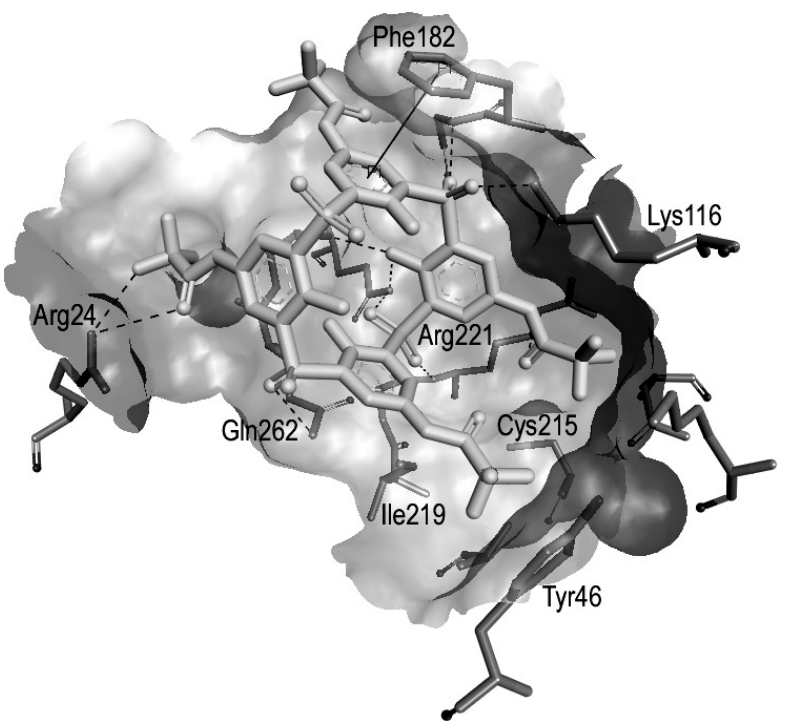

Fig. 5. The posible binding mode of compound 3 at the active site of PTP1B after MD

phate were of $2 \mathrm{mM}$ for PTP1B, TC-PTP, $5 \mathrm{mM}$ for MEG1, MEG2, $7 \mathrm{mM}$ for SHP2, and $1 \mathrm{mM}$ for PTP $\beta$ corresponding to $\mathrm{K}_{m}$ values of the enzymes. The final volume of the assay solution was $0.5 \mathrm{ml}$. The mixture was thermostated at $25^{\circ} \mathrm{C}$ (MEG1, MEG2), $37^{\circ} \mathrm{C}$ (PTP1B) and $30^{\circ} \mathrm{C}$ (TC-PTP, SHP2, PTP $\beta$ ) for $5 \mathrm{~min}$, and the reaction was initiated by addition of the enzyme ( $4-8 \mathrm{nM}$ in the reaction mixture). The $p$-nitrophenol released was determined by reading the absorbance at $410 \mathrm{~nm}$ $\left(\varepsilon=18.000 \mathrm{M}^{-1} \mathrm{~cm}^{-1}\right)$.

\section{Computer modeling}

The molecular docking studies were performed by AutoDock Vina [23] program using X-ray crystals of four centroids of PTP1B clasters (PDB codes: 1NL9, 1PHO, 1Q6M, 2CM8) [24]. The structures of four ligand conformers were prepared by program Avogadro and optimized in MMFF94s force field [25]. The conformers were docked to the active site region of PTP1B. The ligands presented and water molecules were removed from PDB-files before calculations.

Molecular dynamic simulations (MD) of the complexes was performed with NAMD 2.10 [26] using the CHARMM27 and the CHARMM36 force field. The topology parameters for all conformers of compound $\mathbf{3}$ were built using SwissParam server [27]. The preliminary preparation of the parameter files for PTP1B was performed by means of VND 1.9.2 [28]. MD was performed in an NPT ensemble using the Langevin thermostat and pressure control. Energy minimization was performed for 10 ps before the simulation, and the subsequent molecular dynamics for 100 ps was conducted at the temperature of $310 \mathrm{~K}$ and $1 \mathrm{~atm}$ pressure. One step of MD was $1 \mathrm{fs}$ with preservation of trajectories for further analysis after every $50 \mathrm{fs}$.

\section{Conclusions}

Sulfonylcalix[4]arene can be used as a novel scaffold for designing PTPs inhibitors. The sulfonylcalix [4]arene-tetrakis-trifluoroacetamide was found to inhibit PTP1B with $\mathrm{IC}_{50}$ value in the micromolar range and selectivity over other PTPs, such as TC-PTP, MEG1, MEG2, SHP2, and PTP $\beta$. This approach provides a way to new PTP1B inhibitors functionalized by non-ionizable groups on the upper rim of the macrocycle.

Conflicts of Interests: authors have no coflict of interests to declare.

\section{References}

1. Cohen, P. The regulation of protein function by multisite phosphorylation a 25 year update / P. Cohen // Trends Biochem. Sci. - 2000. - Vol. 25, Issue 12. - P. 596-601. https://doi.org/10.1016/s0968-0004(00)01712-6

2. Hunter, T. Signaling-2000 and beyond / T. Hunter // Cell. - 2000. - Vol. 100, Issue 1. - P. 113-127. https://doi.org/10.1016/s0092-8674(00)81688-8

3. Zhang, Z-Y. Protein tyrosine phosphatases: prospects for therapeutics / Z-Y. Zhang // Curr. Opin. Chem. Biol. - 2001. - Vol. 5, Issue 4. - P. 416-423. https://doi.org/10.1016/s1367-5931(00)00223-4

4. Tonks, N. K. Protein tyrosine phosphatases - from housekeeping enzymes to master regulators of signal transduction / N. K. Tonks // FEBS J. 2013. - Vol. 280, Issue 2. - P. 346-378. https://doi.org/10.1111/febs.12077

5. Protein tyrosine phosphatases as potential therapeutic targets / R. J. He, Z. H. Yu, R. Y. Zhang, Z. Y. Zhang // Acta Pharmacol. Sin. - 2014. - Vol. 35, Issue 10. - P. 1227-1246. https://doi.org/10.1038/aps.2014.80

6. Mandolini, L. Calixarenes in Action / L. Mandolini, R. Ungaro // World Sci. Pub. Co. - 2000.

7. Joseph, R. Ion and molecular recognition by lower rim 1,3-di-conjugates of calix[4]arene as receptors / R. Joseph, C. P. Rao // Chem. Rev. - 2011. Vol. 111, Issue 8. - P. 4658-4702. https://doi.org/10.1021/cr1004524

8. Naseer, M. M. Functionalized calix[4] arenes as potential therapeutic agents / M. M. Naseer, M. Ahmed, S. Hameed // Chem. Biol. Drug Des. - 2017. Vol. 89, Issue 2. - P. 243-256. https://doi.org/10.1111/cbdd.12818

9. Molenveld, P. Dinuclear metallo-phosphodiesterase models: application of calix[4]arenes as molecular scaffolds / P. Molenveld, J. F. Engbersen, D. N. Reinhoudt // Chem. Soc. Rev. - 2000. - Vol. 29, Issue 2. - P. 75-86. https://doi.org/10.1039/a804295k

10. Casnati, A. Peptido-and glycocalixarenes: playing with hydrogen bonds around hydrophobic cavities / A. Casnati, F. Sansone, R. Ungaro // Acc. Chem. Res. - 2003. - Vol. 36, Issue 4. - P. 246-254. https://doi.org/10.1021/ar0200798

11. Moulding calixarenes for biomacromolecule targeting / M. Giuliani, I. Morbioli, F. Sansone, A. Casnati // Chem. Comm. - 2015. - Vol. 51, Issue 75. P. 14140-14159. https://doi.org/10.1039/c5cc05204a

12. Calix[4] arene methylenebisphosphonic acids as inhibitors of protein tyrosine phosphatase 1B / V. V. Trush, S. O. Cherenok, V. Yu. Tanchuk et al. // Bioorg. Med. Chem. Lett. - 2013. - Vol. 23, Issue 22. - P. 5619-5623. https://doi.org/10.1016/j.bmcl.2013.08.040

13. Phosphonate monoesters on a thiacalix[4]arene framework as potential inhibitors of protein tyrosine phosphatase 1B / V. V. Trush, S. G. Kharchenko, V. Yu. Tanchuk et al. // Org. Biomol. Chem. - 2015. - Vol. 13, Issue 33. - P. 8803-8806. https://doi.org/10.1039/c5ob01247c

14. Sulfonyl-bridged calix[4]arene as an inhibitor of protein tyrosine phosphatases / V. Buldenko, O. Kobzar, V. Trush et al. // Fr.-Ukr. J. Chem. - 2017. Vol. 5, Issue 2. - P. 144-151. https://doi.org/10.17721/fujcv5i2p144-151

15. Gutsche, C. D. Calixarenes: An Introduction / C. D. Gutsche // RSC. - 2008. - Issue 10.

16. Barford, D. Crystal structure of human protein tyrosine phosphatase 1B / D. Barford, A. J. Flint, N. K. Tonks // Sci. - 1994. - Vol. 263, Issue 5152. P. 1397-1404. https://doi.org/10.1126/science.8128219

17. Montalibet, J. Residues distant from the active site influence protein-tyrosine phosphatase 1B inhibitor binding / J. Montalibet, K. Skorey, D. McKay et al. // J. Bio. Chem. - 2006. - Vol. 281, Issue 8. - P. 5258-5266. https://doi.org/10.1074/jbc.m511546200

18. Kamerlin, S. C. L. A targeted molecular dynamics study of WPD loop movement in PTP1B / S. C. L. Kamerlin, R. Rucker, S. Boresch // Biochem. Biophys. Res. Commun. - 2006. - Vol. 345, Issue 3. - P. 1161-1166. https://doi.org/10.1016/j.bbrc.2006.04.181 
19. Thia- and sulfonyl-calix[4]arene methylphosphonous acids: Synthesis, structure, and amino acids binding / S. G. Kharchenko, A. B. Drapailo, O. I. Kalchenko et al. // Phosph. Sulfur Silicon. - 2013. - Vol. 188, Isssue 1-3. - P. 243-248. https://doi.org/10.1080/10426507.2012.741164

20. Selective oxidation of thiacalix[4]arenes to the sulfinyl- and sulfonylcalix[4]arenes and their coordination ability to metal ions / N. Iki, H. Kumagai, N. Morohashi et al. // Tetrahedron Lett. - 1998. - Vol. 39, Issue 41. - P. 7559-7562. https://doi.org/10.1016/s0040-4039(98)01645-1

21. Facile synthesis of p-tert-butylthiacalix[4]arene by the reaction of p-tert-butylphenol with elemental sulfur in the presence of a base / H. Kumagai, M. Hasegawa, S. Miyanari et al. // Tetrahedron Lett. - 1997. - Vol. 38, Issue 22. - P. 3971-3972. https://doi.org/10.1016/s0040-4039(97)00792-2

22. The inhibitory potential of calixarenes against nucleotide pyrophosphatase/phosphodiesterase 1 / V. Buldenko, L. Kononets, O. Kobzar, et al. // Журн. орг. та фармац. хімії. - 2017. - Vol. 15, Issue 4 (60). - P. 41-47. https://doi.org/10.24959/ophcj.17.928

23. Trott, O. AutoDock Vina: improving the speed and accuracy of docking with a new scoring function, efficient optimization, and multithreading / O. Trott, A. J. Olson // J. Comput. Chem. - 2010. - Vol. 31, Issue 2. - P. 455-461. https://doi.org/10.1002/jcc.21334

24. Tanchuk V. Yu. Classification of binding site conformations of protein tyrosine phosphatase 1B / V. Yu. Tanchuk, V. O. Tanin, A. I. Vovk // Chem. Biol. Drug Des. - 2012. - Vol. 80, Issue 1. - P. 121-128. https://doi.org/10.1111/j.1747-0285.2012.01370.x

25. Hanwell, M. D., Avogadro: an advanced semantic chemical editor, visualization, and analysis platform / M. D. Hanwell, D. E. Curtis, D. C. Lonie et al. // J. Cheminform. - 2012. - Vol. 4, Issue 1. - P. 17. https://doi.org/10.1186/1758-2946-4-17

26. Scalable molecular dynamics with NAMD / J. C. Phillips, R. Braun, W. Wang et al. // J. Comput. Chem. - 2005. - Vol. 26. - P. 1781-1802. https:// doi.org/10.1002/jcc.20289

27. SwissParam, a fast force field generation tool for small organic molecules / V. Zoete, M. A. Cuendet, A. Grosdidier et al. // J. Comput. Chem. - 2011. Vol. 32, Issue 11. - P. 2359-2368. https://doi.org/10.1002/jcc.21816

28. Humphrey, W. VMD: visual molecular dynamics / W. Humphrey, A. Dalke, K. Schulten // J. Mol. Graph. - 1996. - Vol. 14, Issue 1. - P. 33-38. https://doi.org/10.1016/0263-7855(96)00018-5

\section{References}

1. Cohen, P. (2000). The regulation of protein function by multisite phosphorylation - a 25 year update. Trends in Biochemical Sciences, 25(12), 596-601. https://doi.org/10.1016/s0968-0004(00)01712-6

2. Hunter, T. (2000). Signaling-2000 and Beyond. Cell, 100(1), 113-127. https://doi.org/10.1016/s0092-8674(00)81688-8

3. Zhang, Z.-Y. (2001). Protein tyrosine phosphatases: prospects for therapeutics. Current Opinion in Chemical Biology, 5(4), 416-423. https:// doi.org/10.1016/s1367-5931(00)00223-4

4. Tonks, N. K. (2013). Protein tyrosine phosphatases - from housekeeping enzymes to master regulators of signal transduction. FEBS Journal, 280(2), 346-378. https://doi.org/10.1111/febs.12077

5. He, R., Yu, Z., Zhang, R., \& Zhang, Z. (2014). Protein tyrosine phosphatases as potential therapeutic targets. Acta Pharmacologica Sinica, 35(10), 1227-1246. https://doi.org/10.1038/aps.2014.80

6. Mandolini, L., Ungaro, R. (2000). Calixarenes in Action. World Scientific Pub. Co.

7. Joseph, R., \& Rao, C. P. (2011). Ion and Molecular Recognition by Lower Rim 1,3-Di-conjugates of Calix[4]arene as Receptors. Chemical Reviews, 111(8), 4658-4702. https://doi.org/10.1021/cr1004524

8. Naseer, M. M., Ahmed, M., \& Hameed, S. (2017). Functionalized calix[4]arenes as potential therapeutic agents. Chemical Biology \& Drug Design, 89(2), 243-256. https://doi.org/10.1111/cbdd.12818

9. Molenveld, P., Engbersen, J. F. J., \& Reinhoudt, D. N. (2000). Dinuclear metallo-phosphodiesterase models: application of calix[4]arenes as molecular scaffolds. Chemical Society Reviews, 29(2), 75-86. https://doi.org/10.1039/a804295k

10. Casnati, A., Sansone, F., \& Ungaro, R. (2003). Peptido- and Glycocalixarenes: Playing with Hydrogen Bonds around Hydrophobic Cavities. Accounts of Chemical Research, 36(4), 246-254. https://doi.org/10.1021/ar0200798

11. Giuliani, M., Morbioli, I., Sansone, F., \& Casnati, A. (2015). Moulding calixarenes for biomacromolecule targeting. Chemical Communications, 51(75), 14140-14159. https://doi.org/10.1039/c5cc05204a

12. Trush, V. V., Cherenok, S. O., Tanchuk, V. Y., Kukhar, V. P., Kalchenko, V. I., \& Vovk, A. I. (2013). Calix[4]arene methylenebisphosphonic acids as inhibitors of protein tyrosine phosphatase 1B. Bioorganic \& Medicinal Chemistry Letters, 23(20), 5619-5623. https://doi.org/10.1016/j.bmcl.2013.08.040

13. Trush, V. V., Kharchenko, S. G., Tanchuk, V. Y., Kalchenko, V. I., \& Vovk, A. I. (2015). Phosphonate monoesters on a thiacalix[4]arene framework as potential inhibitors of protein tyrosine phosphatase 1B. Organic \& Biomolecular Chemistry, 13(33), 8803-8806. https://doi.org/10.1039/c5ob01247c

14. Buldenko, V., Kobzar, O., Trush, V., Drapailo, A., ... Kalchenko, V. (2017). Sulfonyl-bridged Calix[4]arene as an Inhibitor of Protein Tyrosine Phosphatases. French-Ukrainian Journal of Chemistry, 5(2), 144-151. https://doi.org/10.17721/fujcv5i2p144-151

15. Gutsche, C. D. (2008). Calixarenes: an introduction. Royal Society of Chemistry, 10.

16. Barford, D., Flint, A., \& Tonks, N. (1994). Crystal structure of human protein tyrosine phosphatase 1B. Science, 263(5152), 1397-1404. https:// doi.org/10.1126/science.8128219

17. Montalibet, J., Skorey, K., McKay, D., Scapin, G., Asante-Appiah, E., \& Kennedy, B. P. (2006). Residues Distant from the Active Site Influence Proteintyrosine Phosphatase 1B Inhibitor Binding. Journal of Biological Chemistry, 281(8), 5258-5266. https://doi.org/10.1074/jbc.m511546200

18. Kamerlin, S. C. L., Rucker, R., \& Boresch, S. (2006). A targeted molecular dynamics study of WPD loop movement in PTP1B. Biochemical and Biophysical Research Communications, 345(3), 1161-1166. https://doi.org/10.1016/j.bbrc.2006.04.181

19. Kharchenko, S. G., Drapailo, A. B., Kalchenko, O. I., Yampolska, G. D., Shishkina, S. V., Shishkin, O. V., \& Kalchenko, V. I. (2013). Thia- and SulfonylCalix[4]Arene Methylphosphonous Acids: Synthesis, Structure, and Amino Acids Binding. Phosphorus, Sulfur, and Silicon and the Related Elements, 188(1-3), 243-248. https://doi.org/10.1080/10426507.2012.741164

20. Iki, N., Kumagai, H., Morohashi, N., Ejima, K., Hasegawa, M., Miyanari, S., \& Miyano, S. (1998). Selective oxidation of thiacalix[4]arenes to the sulfinyl- and sulfonylcalix[4]arenes and their coordination ability to metal ions. Tetrahedron Letters, 39(41), 7559-7562. https://doi.org/10.1016/ s0040-4039(98)01645-1

21. Kumagai, H., Hasegawa, M., Miyanari, S., Sugawa, Y., Sato, Y., Hori, T., ... Miyano, S. (1997). Facile synthesis of p-tert-butylthiacalix[4]arene by the reaction of p-tert-butylphenol with elemental sulfur in the presence of a base. Tetrahedron Letters, 38(22), 3971-3972. https://doi.org/10.1016/ s0040-4039(97)00792-2

22. Buldenko, V., Kononets, L., Kobzar, O., Drapailo, A., Vyshnevsky, S., Kalchenko, V., \& Vovk, A. (2017). The inhibitory potential of calixarenes against nucleotide pyrophosphatase/phosphodiesterase 1. Žurnal organičnoï ta farmacevtičnoï hìmï̈, 15(4(60)), 41-47. https://doi.org/10.24959/ophcj.17.928

23. Trott, O., \& Olson, A. J. (2009). AutoDock Vina: Improving the speed and accuracy of docking with a new scoring function, efficient optimization, and multithreading. Journal of Computational Chemistry, 31(2), 455-461. https://doi.org/10.1002/jcc.21334

24. Tanchuk, V. Y., Tanin, V. O., \& Vovk, A. I. (2012). Classification of Binding Site Conformations of Protein Tyrosine Phosphatase 1B. Chemical Biology \& Drug Design, 80(1), 121-128. https://doi.org/10.1111/j.1747-0285.2012.01370.x

25. Hanwell, M. D., Curtis, D. E., Lonie, D. C., Vandermeersch, T., Zurek, E., \& Hutchison, G. R. (2012). Avogadro: an advanced semantic chemical editor, visualization, and analysis platform. Journal of Cheminformatics, 4(1), 17. https://doi.org/10.1186/1758-2946-4-17

26. Phillips, J. C., Braun, R., Wang, W., Gumbart, J., Tajkhorshid, E., Villa, E., ... Schulten, K. (2005). Scalable molecular dynamics with NAMD. Journal of Computational Chemistry, 26(16), 1781-1802. https://doi.org/10.1002/jcc.20289

27. Zoete, V., Cuendet, M. A., Grosdidier, A., \& Michielin, O. (2011). SwissParam: A fast force field generation tool for small organic molecules. Journal of Computational Chemistry, 32(11), 2359-2368. https://doi.org/10.1002/jcc.21816

28. Humphrey, W., Dalke, A., \& Schulten, K. (1996). VMD: Visual molecular dynamics. Journal of Molecular Graphics, 14(1), 33-38.https://doi. org/10.1016/0263-7855(96)00018-5 